\title{
POPULASI DAN DAYA DUKUNG HABITAT RUSA DAN BIAWAK DI TAMAN NASIONAL UJUNG KULON
}

\author{
(Population and Habitat Carrying Capacity of Deer (Cervus timorensis Blainville) \\ and Monitor Lizard (Varanus salvatori Cumingi) in Ujung Kulon National Park)
}

Oleh/By :

Abdullah Syarief Mukhtar

\begin{abstract}
The purpose of this research was to get data and information of population and carrying capacity of deer (Cervus timorensis Blainville) and monitor lizard (Varanus salvatori Cumingi) in Peucang Island, Ujung Kulon National Park, Province of Banten. The research used transects method with the wide of transect was $50 \mathrm{~m}$. Resulst of the research showed deer population in Peucang Island was ranged from 271 deer (on 2001) - 308 deer (on 2000). This fluctuation was caused by two factors that were emigration factor, that was during observation had been met some adult deer group crossed to coast of Ujung Kulon, Java Island and death factor of overage age effect of adult deer group and disease of class group on juvenile. Deer population on 2001 counted 271 deer consist of 131 adults female 104 and male 27), adolescent age class 63 (female 46 and male 17) and juvenile 77 (female 56 and male 21). Deer habitat in Peucang Island from two community types (mangrove and lowland forest) were in the form of grassland, mangrove forest, coastal forest and lowland forest (10-30 $\mathrm{m} \mathrm{ASL}$ ). Carrying capacity of deer habitat in Peucang Island at rainy season was 337 deer, and at this season deer population in twice observation was between $271-308$, which were still in the condition below maximum carrying capacity. Lizards population in Peucang Island was about 55 consisted of 46 adults female 36 and male 10), 7 adolescent (female 5 and male 2) and 2 juvenile (female). Carrying capacity of monitor lizard was equivalent with closeness of optimum population that was 0.13 tail per ha.
\end{abstract}

Key words: Population, carrying capacity, habitat, deer, Cervus timorensis Blainville, monitor lizard, Varanus salvatori Cumingi

\begin{abstract}
ABSTRAK
Tujuan penelitian ini adalah mendapatkan data dan informasi populasi dan daya dukung habitat rusa (Cervus timorensis Blainville) dan biawak (Varanus salvatori Cumingi) di Pulau Peucang Taman Nasional (TN) Ujung Kulon Provinsi Banten. Metode yang digunakan adalah metode Transek Garis dengan lebar transek yaitu kiri kanan garis $50 \mathrm{~m}$. Hasil penelitian menunjukkan populasi rusa di P. Peucang berkisar antara 271 ekor (tahun 2001) - 308 ekor (tahun 2000). Fluktuasi ini disebabkan dua faktor yaitu pertama : emigrasi yaitu selama pengamatan dijumpai beberapa kelompok rusa dewasa menyeberang ke pantai Ujung Kulon daratan P. Jawa, dan kedua : faktor kematian akibat usia yang terlalu tua dari kelompok rusa dewasa dan penyakit dari kelompok kelas umur bayi/anak. Populasi rusa tahun 2001 sebanyak 271 ekor terdiri dari kelas umur dewasa 131 ekor (betina 104 ekor dan jantan 27 ekor), kelas umur remaja 63 ekor (betina 46 ekor dan jantan 17 ekor) dan kelas umur anak/bayi 77 ekor (betina 56 ekor dan jantan 21 ekor). Habitat rusa di P. Peucang dari dua tipe komunitas (mangrove, pantai, dan dataran rendah) berupa padang rumput, hutan mangrove, hutan pantai, dan hutan dataran rendah (10-30 $\mathrm{m}$ dpl). Daya dukung habitat rusa P. Peucang pada musim hujan 337 ekor, dan pada musim ini populasi rusa dalam dua kali pengamatan yaitu antara 271-308 ekor, masih dalam kondisi di bawah daya dukung maksimum. Populasi biawak di P. Peucang sekitar 55 ekor terdiri dari kelompok umur dewasa, 46 ekor (betina 36 ekor dan jantan 10 ekor), remaja 7 ekor (betina 5 ekor dan jantan 2 ekor) dan anak 2 ekor (betina). Daya dukung biawak setara dengan kerapatan populasi optimum yaitu 0,13 ekor per ha.

Kata kunci : Populasi, daya dukung, habitat, rusa, Cervus timorensis Blainville, biawak, Varanus salvatori Cumingi
\end{abstract}




\section{PENDAHULUAN}

Di Indonesia, jenis-jenis satwa yang bernilai ekonomi dan pemanfaatannya tinggi banyak yang belum lengkap datanya terutama mengenai daya dukung habitat dan dinamika populasinya. Sedangkan pemanfaatannya sampai saat ini masih mengandalkan ketersediaan di habitat aslinya. Untuk melestarikan pemanfaatannya dalam rangka memenuhi permintaan pasar yang tinggi, pemerintah tiap tahun mengeluarkan kebijakan penentuan kuota ekspor bagi jenis-jenis satwa liar yang diperdagangkan. Dari hasil evaluasi Ditjen PHPA(kini PHKA) tiap tahun, ternyata pada prakteknya realisasi tangkapan sebagian besar di bawah kuota yang ditargetkan. $\mathrm{Hal}$ ini yang menimbulkan permasalahan, apakah karena penentuan kuota penangkapannya tidak didukung data populasi yang cermat ataukah memang populasi dan habitatnya di alam menurun.

Dari ribuan satwa yang telah ditetapkan kuotanya pada tahun 2001 oleh Ditjen PHKA (No.44/KPTS/Dj-V/2001), berdasarkan pertimbangan dan fasilitas penelitian yang ada, maka jenis yang diprioritaskan untuk diteliti guna menunjang penentuan kuota penangkapan adalah rusa (Cervus timorensis Blainville) dan biawak (Varanus salvatori Cumingi). Rusa (C. timorensis) termasuk hasil hutan nir kayu yang kenyataannya mempunyai nilai ekonomi tinggi. Dagingnya biasa dimanfaatkan masyarakat sebagai sumber protein hewani dan kulitnya sebagai bahan baku industri kerajinan. Karena nilai kegunaannya ini sehingga terjadi penangkapan dalam jumlah banyak terhadap rusa. Sedangkan biawak biasanya digunakan dalam bidang penelitian medis dan kulitnya sebagai bahan baku industri.

Penyebaran jenis satwa liar tersebut hampir $90 \%$ terdapat di hutan produksi, baik berupa lahan basah maupun lahan kering dan ini merupakan hasil hutan nir kayu. Dalam hubungannya dengan hutan produksi alam ini difokuskan untuk ditingkatkan produktivitasnya guna memenuhi kebutuhan masyarakat dan industri hasil hutan secara lestari, termasuk diantaranya industri kulit satwa liar biawak. Untuk mencapai tujuan tersebut perlu dukungan penelitian dan pengembangan serta sistem pemantauan dan evaluasi populasi dan daya dukung habitat satwa liar (antara lain rusa dan biawak), baik yang ada di kawasan konservasi (seperti taman nasional) maupun di luar kawasan
konservasi.

Di sisi lain sebagai konsekuensi pengelolaan yang baik, maka pertumbuhan populasi satwa liar di taman nasional dan kawasan konservasi lain pada umumnya juga akan baik, sehingga pada gilirannya keadaan populasi tersebut akan melebihi daya dukungnya. Apabila ini terjadi, maka dilakukan pengendalian populasi sampai ke tingkat daya dukung habitatnya, seandainya dibiarkan akan berakibat negatif terhadap rusa darian satwa liar itu sendiri. Karena ekonomiawak sebagai satwa yang bernilai tersebut tinggi, maka kelimpahan populasi kesejahteraan dimanfaatkan untuk sistem pengemasyarakat, dengan caral Dalam pelakembangan rekreasi berburu. selektif kelas unaan rekreasi berburu perlu berapa jumlahnur mana yang boleh diburu, dengan demikian dan pada musim apa, menjadi hal yan dukungan hasil penelitian Tujuan yang penting.

mendapatkan penelitian ini adalah dan daya dukung dan informasi populasi di T.N. Ujung Kung habitat rusa dan biawak adalah tersed Kulon. Sasaran penelitian tentang populanya data dan informasi rusa di P. Peucan dan daya dukung habitat dukung habitat serta populasi dan daya Ujung Kulon. Hasil

adalah :

1. Dat

$$
\begin{aligned}
& \text { 1. Data dan informasi populasi dan daya } \\
& \text { dukung habitat rusa dan biawak dapat } \\
& \text { dijadikan salah satu acuan dalam } \\
& \text { memantapkan rencana pengelolaan } \\
& \text { kawasan dan pengelolaan populasi satwa } \\
& \text { liar di TN. Ujung Kulon khususnya di } \\
& \text { wilayah kepulauan. } \\
& \text { 2. Dapat dijadikan bahan pertimbangan untuk } \\
& \text { mendukung pemanfaatan satwa liar } \\
& \text { dalam sistem rekreasi berburu di zonatemata }
\end{aligned}
$$


pemanfaatan TN Ujung Kulon sebagai pelaksanaan pengendalian populasi dari kedua jenis satwa tersebut.

\section{METODE PENELITIAN}

\section{A. Bahan dan Peralatan}

Obyek yang diteliti yaitu komponen habitat (tempat mencari makan, minum, kawin, lahir, bermain, dan berlindung). Bahan dan peralatan yang dipergunakan antara lain : kompas, teropong, handytalky, meteran ( $30 \mathrm{~m})$, altimeter, tustel, timbangan pegas, tambang plastik, tali rapia, alat tulis, alkohol $95 \%$, jeroan (umpan biawak), dan lain-lain.

\section{B. Lokasi dan Waktu Penelitian}

Lokasi penelitian yaitu P. Peucang, Taman Nasional Ujung Kulon (TNUK), Provinsi Banten. Alasan pemilihan lokasi ini adalah: (1) memenuhi syarat untuk mendapatkan suatu teknologi sebagaimana dimaksud dalam judul penelitian; (2) lokasi penelitian merupakan zona pemanfaatan TN Ujung Kulon yang pada dewasa ini pemanfaatan dalam bentuk pengusahaan pariwisata alam dilaksanakan oleh pihak ketiga yang berbadan hukum yaitu PT. Wana Wisata. Dengan demikian hasil penelitian diharapkan mendukung pemanfaatan tersebut, dalam kaitannya diduga bahwa populasi rusa dan biawak telah melampaui daya dukungnya.

Kegiatan penelitian dilakukan selama dua periode yaitu bulan Juli/Agustus dan bulan Nopember 2001. Di samping itu, data populasi rusa sebelumnya juga telah dikumpulkan pada tahun 2000 di lokasi yang sama di P. Peucang, TN Ujung Kulon.

\section{Cara Pengambilan Data}

\section{Populasi}

Metode yang digunakan untuk menentukan populasi satwa yang diteliti adalah Metode Garis Transek dengan lebar jalur yang sama yaitu kiri-kanan jalur $50 \mathrm{~m}$. Metode ini merupakan salah satu metode sensus satwa liar secara langsung.
Kegiatan yang dilakukan dalam metode garis transek adalah sebagai berikut :

(1) Garis transek ke I diletakkan di bagian selatan P. Peucang. Titik awal sebagai titik pasti yaitu ditentukan di lapangan dan dari titik ini dengan bantuan kompas dibuat transek garis dari arah barat ke timur P. Peucang. Penentuan arah ini didasarkan pada arah angin yang berlawanan arah garis transek sehingga rusa dan biawak saat penelitian tidak merasa terganggu. Garis transek ini diletakkan secara sistematik dari arah selatan ke utara P. Peucang dengan interval $100 \mathrm{~m}$, sehingga jumlah keseluruhannya 5 garis transek. Semua garis transek dan informasi lainnya diplotkan pada peta kerja skala 1 : 50.000 yang telah dilengkapi informasi kontur dan tipe vegetasi.

(2) Tenaga kerja pada setiap garis transek sebanyak 3 orang dengan pembagian tugas kerja yaitu seorang pencatat dan dua orang tenaga pembantu. Masingmasing regu pengamat dibekali peta kerja skala 1 : 50.000, peralatan teropong, alat ukur meteran, kompas dan tally sheet serta peralatan lapangan lainnya yang sifatnya menunjang. Tiga regu lainnya masing-masing dilengkapi dengan satu unit tustel dan handy talky.

(3) Tenaga pencatat berjalan sepanjang garis transek dengan mencatat jumlah rusa yang terlihat, jenis kelamin, kelas umur, jarak dari posisi rusa dengan pencatat, perilaku, dan tanda-tanda khusus lainnya

(4) Pelaksanaan kegiatan penelitian dilakukan secara serentak dari ke-5 regu tersebut yaitu mulai pagi jam 6.00 sampai selesai sesuai dengan panjang transek yang ditempuh. Dengan demikian diasumsikan tidak ada rusa yang terhitung dua kali.

Pencatatan jumlah individu dalam suatu populasi digunakan cara Van Lavieren (1983) dan metode konsentrasi serta analisis pertumbuhannya dari tahun ke tahun digunakan perhitungan dan tabulasi dengan Model Matriks Leslie, sedangkan laju reproduksi neto, laju pertumbuhan tahap 
awal dan lamanya reproduksi dapat digunakan perhitungan dan tabulasi dengan life table (neraca kehidupan).

\section{Daya Dukung}

Cara pembuatan petak coba dan pengukuran produksi rumput ditentukan dengan cara pemangkasan rumput sampai batas pangkal akar pada 20 petak cuplikan yang menyebar secara acak di padang rumput dengan masing-masing petak berukuran $1 \mathrm{~m} \mathrm{x} 1 \mathrm{~m}$. Untuk hijauan lain bukan rumput (daun-daunan pohon, semak, dan anakan) dengan cara pemangkasan daun setinggi $2 \mathrm{~m}$ ke bawah (sebatas jangkauan rusa) pada 20 petak contoh yang masingmasing berukuran $3 \mathrm{~m} \mathrm{x} 3 \mathrm{~m}$ yang terletak secara sistematik memotong pulau dari arah sedang mencari makan. Masing-masing petak dipagar sedemikian rupa sehingga selama penelitian bebas dari gangguan satwa liar.

Interval waktu pemangkasan, baik untuk rumput maupun hijauan lainnya yaitu 40 hari untuk musim hujan dan 60 hari untuk musim kemarau. Pemangkasan rumput dan hijauan lainnya dilakukan dua kali. Pada setiap petak, hasil pemangkasan rumput atau hijauan lainnya ditimbang untuk dikeringkan pada oven dengan suhu $50^{\circ} \mathrm{C}$ untuk mendapatkan berat kering yang stabil.

Besarnya daya dukung, cara pengumpulan data dan analisisnya dapat digunakan modifikasi dari cara Castle (1955) barat ke timur di P. Peucang, dengan jarak antar petak $100 \mathrm{~m}$. Lokasi petak ditentukan berdasarkan pengamatan pendahuluan pada daerah yang sering dijumpai rusa yang mendapatkan berat segar, kemudian

jumlah pakan per hari per ekor rata-rata yang dikonsumsi.

\section{Analisis Data}

\section{Populasi}

Dari hasil pencatatan data tiap garis transek, populasi rusa/biawak dihitung dengan menggunakan rumus:

dimana. $P_{D}=\frac{A Z}{2 \times D}$

$P_{D}=$ Populasi rusa/biawak dengan menggunakan rataan jarak pengamatan.

$A=$ Luas areal sensus

$\mathrm{Z}$ = Jumlah satwa yang diamati

$D$ = Rataan jarak pengamatan

2D = Lebar jalur efektip pengamatan satwa sebelah kiri-kanan jalur = luas areal contoh

$$
\mathrm{D}=\mathrm{a} \times \mathrm{D} 1 \times \mathrm{b} \times \mathrm{D} 2 \times \mathrm{c} \times \mathrm{D} 3
$$

Dimana:

\section{Z}

$$
\begin{gathered}
\mathrm{a}, \mathrm{b}, \mathrm{c}=\text { jumlah rusa/biawak yang } \\
\text { diamati pada setiap posisi } \\
\text { pengamat } \\
\mathrm{D} 1, \mathrm{D} 2, \mathrm{D} 3=\text { Jarak rusa/biawak } \\
\text { terhadap setiap posisi } \\
\text { pengamat }
\end{gathered}
$$

\section{Daya Dukung \\ Berdasarkan daya dukung dapat dihitung 1975):}

\section{a. Daya Dukung Pada Musim Hujan :}

$$
\begin{aligned}
& \text { Interval waktu pemangkasan (40 hari) } \\
& \text { Produksi hijauan total } / 40 \text { hari }=\left\{\text { Produksi rumput } 40 \text { hari }\left(\text { gram } / m^{2}\right) \times \text { makan rusa/ekor } /\right. \text { musim hujan } \\
& \text { \{Produksi hijauan bukan rumput/ } \left.\mathrm{m}^{2}\right) \times \\
& \text { luas areal hijauan bukan rumput } / 40 \text { hari }\left(g r a m / m^{2}\right) \times \text { a } \\
& \text { Kebutuhan makan rusa/ekor/musim hujan = lamanya musim } \\
& \begin{array}{l}
\text { lamanya musim hujan (hari) } \mathrm{x} \text { kebutuhan makan seekor } \\
\text { rusa/hari }
\end{array}
\end{aligned}
$$

dalam McIlroy (1964) yaitu jumlah ketersediaan pakan dalam suatu habitat dan 
dihitung dengan persamaan sebagai berikut:

$$
\mathbf{G}=\mathbf{G} \mathbf{0}-\mathbf{G 1}
$$

dimana :

$$
\begin{aligned}
\mathrm{G}= & \text { berat hijauan yang dimakan } \\
& \text { seekor rusa perhari }(\mathrm{kg}) ; \\
\mathrm{G} 0= & \text { berat hijauan sebelum dimakan } \\
& (\mathrm{kg}) \\
\mathrm{Gl}= & \text { berat hijauan setelah dimakan } \\
& \text { rusa/ekor/hari }(\mathrm{kg}) .
\end{aligned}
$$

b. Daya Dukung Pada Musim Kemarau :

$$
\frac{\text { Lamanya musim kemarau (hari) }}{\text { Interval waktu pemangkasan ( } 60 \text { hari) }} \times \frac{\text { Produksi hijauan total/60 hari }}{\text { Kebutuhan makan rusa/ekor/musim kemarau }}
$$

Produksi hijauan total $/ 60$ hari $=\left\{\right.$ Produksi rumput $/ 60$ hari $\left(\mathrm{gram} / \mathrm{m}^{2}\right) \times$ luas areal rumput $\left.\left.\times \mathrm{p} . \mathrm{u}\right)\right\}+$ \{Produksi hijauan bukan rumput/60 hari $\left(\mathrm{gram} / \mathrm{m}^{2}\right) \times$

luas areal hijauan bukan rumput $x$ p.u\}

Besarnya proper use (p.u) untuk rumput $=70 \%$ (penggunaan berat) dan p.u. untuk hijauan bukan rumput sebesar $45 \%$ (penggunaan sedang).

Kebutuhan makan rusa/ekor/musim kemarau = lamanya musim kemarau (hari) $\mathrm{x}$ kebutuhan makan rusa/ ekor/hari

\section{HASIL DAN PEMBAHASAN}

\section{A. Rusa (C. timorensis)}

\section{Populasi, Kelas Umur dan Nisbah Kelamin}

Berdasarkan hasil pengamatan, bahwa jumlah rusa di P. Peucang sekitar 271 ekor terdiri dari kelas umur dewasa 131 ekor (betina 104 ekor dan jantan 27 ekor), kelas umur remaja 63 ekor (betina 46 ekor dan jantan 17 ekor) dan kelas umur anak/bayi 77

\begin{tabular}{|c|c|c|c|c|c|c|c|c|c|}
\hline \multirow{3}{*}{ No. } & \multirow{3}{*}{$\begin{array}{c}\text { Lokasi } \\
\text { (Location) }\end{array}$} & \multicolumn{6}{|c|}{ Kelas Umur (Age Class/Year) } & \multirow{2}{*}{\multicolumn{2}{|c|}{$\begin{array}{l}\text { Jumlah } \\
\text { (Total) }\end{array}$}} \\
\hline & & \multicolumn{2}{|c|}{$\begin{array}{l}\text { Dewasa } \\
\text { (Adult) }\end{array}$} & \multicolumn{2}{|c|}{$\begin{array}{c}\text { Remaja } \\
\text { (Adolescent) }\end{array}$} & \multicolumn{2}{|c|}{$\begin{array}{c}\text { Anak } \\
\text { (Juvenile) }\end{array}$} & & \\
\hline & & + & 6 & + & 8 & $q$ & $\delta$ & $q$ & $\delta$ \\
\hline 1. & Padang Rumput & 16 & 4 & 5 & 1 & 8 & 2 & 29 & 7 \\
\hline 2. & Jl. Ke Kr. Copong & 23 & 7 & 12 & 7 & 14 & 9 & 49 & 23 \\
\hline 3. & Lg. Beton & 3 & 1 & 2 & - & - & - & 5 & 1 \\
\hline 4. & Cihandarusa & 16 & 5 & 9 & 3 & 12 & 5 & 37 & 13 \\
\hline 5. & Belakang Diesel & 12 & 2 & 4 & 1 & 6 & 3 & 20 & 7 \\
\hline 6. & Kr. Copong & 8 & 2 & 2 & - & 3 & - & 13 & 2 \\
\hline 7. & G. Peucang Barat & 4 & 1 & 3 & 2 & 1 & 1 & 8 & 4 \\
\hline 8. & Ciapus & 7 & 3 & 2 & - & 4 & 2 & 13 & 5 \\
\hline 9. & Lg. Kobak & 6 & 1 & 1 & - & 2 & 1 & 9 & 2 \\
\hline 10. & Lg. Sumino & 3 & 1 & 2 & - & 1 & - & 6 & 1 \\
\hline 11. & GB Peucang Timur & 10 & 4 & 4 & 3 & 5 & 2 & 19 & 9 \\
\hline 12. & Ranca Waru & 7 & 2 & 2 & 1 & 4 & - & 13 & 3 \\
\hline 13. & Lg. Madura & 6 & 2 & - & - & 2 & - & 8 & 2 \\
\hline & Jumlah (Total) & 122 & 36 & 48 & 18 & 62 & 25 & 229 & 79 \\
\hline
\end{tabular}
ekor (betina 56 ekor dan jantan 21 ekor). Secara rinci data populasi di berbagai lokasi pengamatan P. Peucang seperti terlihat pada Tabel 1 dan Tabel 2.

Tabel (Table) 1. Populasi rusa (C. timorensis) di Pulau Peucang T.N. Ujung Kulon Provinsi Banten, tahun 2000 (Deer population in Peucang Island, Ujung Kulon National Park, Banten Province, 2000) 
Tabel (Table) 2. Populasi rusa (C. timorensis) di Pulau Peucang T. N. Ujung Kulon Provinsi Banten, tahun 2001 (Deer population in Peucang Island, Ujung Kulon
National Park, Banten Province, 2001).

\begin{tabular}{|c|c|c|c|c|c|c|c|c|c|}
\hline \multirow[b]{2}{*}{ No. } & \multirow{2}{*}{$\begin{array}{c}\text { Lokasi } \\
\text { Location }\end{array}$} & \multicolumn{6}{|c|}{ Kelas Umur (Age Class/Year) } & \multirow{2}{*}{\multicolumn{2}{|c|}{$\begin{array}{c}\text { Jumlah } \\
\text { (Total) }\end{array}$}} \\
\hline & & \multicolumn{2}{|c|}{$\begin{array}{l}\text { Dewasa } \\
\text { (Adult) }\end{array}$} & \multicolumn{2}{|c|}{$\begin{array}{c}\text { Remaja } \\
\text { (Adolescent) }\end{array}$} & \multicolumn{2}{|c|}{$\begin{array}{c}\text { Anak } \\
\text { (Juvenile) }\end{array}$} & & \\
\hline 1. & Padang Rumput & $\frac{q}{13}$ & $\frac{8}{3}$ & $q$ & 6 & 9 & $\delta$ & q & $\delta$ \\
\hline 2. & Jl. Ke Kr. Copong & 19 & $\frac{3}{6}$ & 5 & 1 & 7 & 2 & 25 & 6 \\
\hline 3. & Lg. Beton & 2 & $\frac{6}{1}$ & $\frac{10}{2}$ & 6 & 11 & 7 & 40 & 19 \\
\hline 4. & Cihandarusa & 14 & 4 & $\frac{2}{9}$ & - & - & - & 4 & 1 \\
\hline 5. & Belakang Diesel & 9 & 2 & $\frac{9}{4}$ & 3 & 10 & 3 & 33 & 10 \\
\hline 6. & Kr. Copong & 9 & 2 & $\frac{4}{2}$ & 1 & 6 & 3 & 19 & 6 \\
\hline 7. & G. Peucang Barat & 3 & 1 & $\frac{2}{3}$ & - & 3 & - & 14 & 2 \\
\hline 8. & Ciapus & 7 & 2 & $\frac{3}{2}$ & 2 & 1 & 1 & 7 & 4 \\
\hline 9. & Lg. Kobak & 5 & 1 & $\frac{2}{1}$ & - & 4 & 2 & 13 & 4 \\
\hline 10. & Lg. Sumino & 3 & 1 & $\frac{1}{2}$ & - & 2 & 1 & 8 & 2 \\
\hline 11. & GB Peucang Timur & 9 & 2 & $\frac{2}{4}$ & - & 1 & - & 6 & $\frac{2}{1}$ \\
\hline 12. & Ranca Waru & 6 & 1 & $\frac{7}{2}$ & 3 & 5 & 2 & 18 & 7 \\
\hline 13. & Madura & 5 & 1 & - & $\frac{1}{-}$ & 4 & - & 12 & 2 \\
\hline & Jumlah (Total) & 107 & 27 & 46 & $\frac{-}{17}$ & 2 & - & 7 & 1 \\
\hline
\end{tabular}

1 dan Tabel 2), kemyata tabel tersebut (Tabel 1 dan Tabel 2), ternyata populasi rusa di. P. Peucang menurun dari 308 ekor menjadi 271. Hal ini disebabkan oleh dua faktor yaitu pertama emigrasi yaitu selama pengamatan dijumpai beberapa kelompok rusa dewasa menyeberang ke pantai Ujung Kulon daratan usia yang kedua faktor kematian karena dewasa, dan penyalua dari kelompok rusa umur bayi/anak.

\section{Struktur Umur}

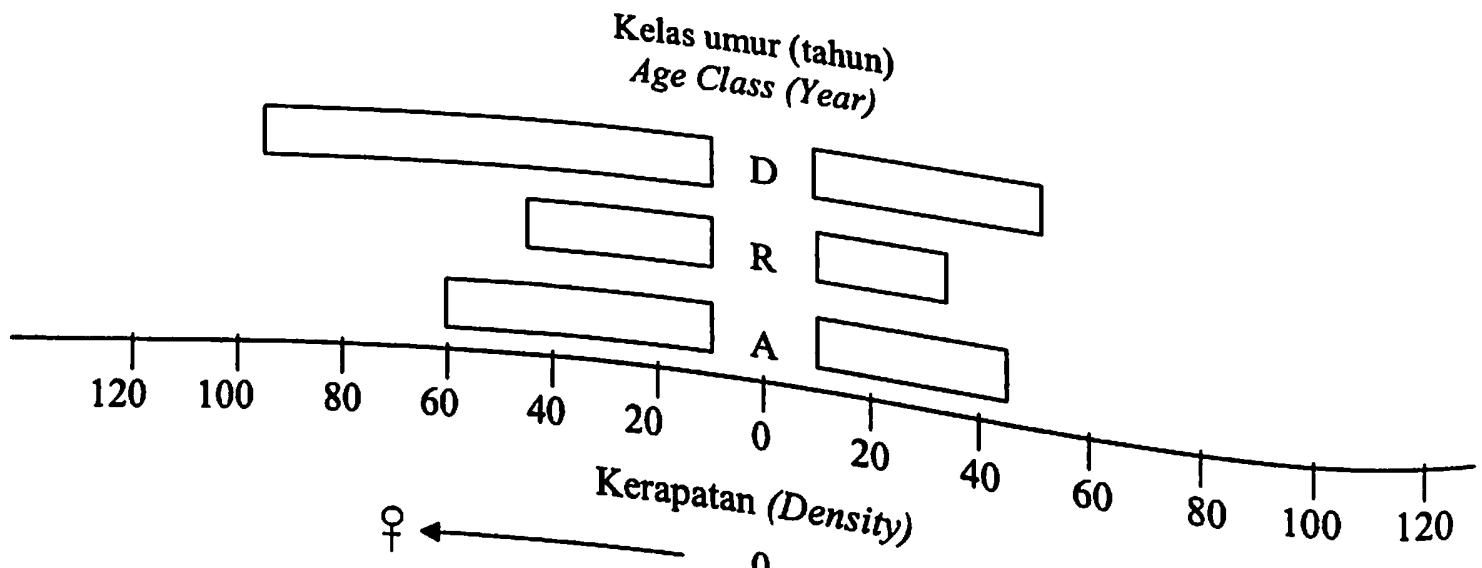

Keterangan (Remarks) $: \mathrm{D}=\operatorname{Dewasa}($ Adult), $\mathrm{R}=\operatorname{Remaja}$ (Adolescent) dan $\mathrm{A}=\mathrm{Anak}$ (Juvenile)
Gambar (Figure) 1. Pola struktur umur por of deer population in Peucang Island) 
Pada Gambar 1 dapat dilihat bahwa nisbah kelamin (sex ratio) rusa jantan dan rusa betina untuk setiap Kelas Umur (KU) berbeda. Untuk KU anak, nisbah kelamin rusa jantan dan rusa betina $1: 3, \mathrm{KU}$ remaja $1: 3$, dan dewasa $1: 4$. Apabila diperhatikan keadaan nisbah kelamin $\mathrm{KU}$ anak, $\mathrm{KU}$ remaja dibandingkan dengan $\mathrm{KU}$ dewasa, cukup mengkhawatirkan jika hanya terlihat pada KU dewasa yang keadaan populasi rusa betina tidak produktif lebih tinggi daripada yang produktif. Namun, kenyataan di lapangan tidak dijumpai kondisi yang mengkhawatirkan tersebut, karena populasi $\mathrm{KU}$ anak saat penelitian lebih banyak dilahirkan dari rusa betina dewasa, berarti memberikan harapan bahwa potensi berbiak rusa di Pulau Peucang cukup tinggi, karena pada KU dewasa ini diduga merupakan masa reproduksi. Walaupun masa reproduksi rusa di Pulau Peucang belum diketahui, tetapi berdasarkan hasil penelitian Mukhtar (1996), bahwa rusa di Sumbawa umur awal berbiak (kehamilan pertama) pada umur 2 tahun 3 bulan, umur berbiak maksimum 10-15 tahun, masa kehamilan 267-284 hari. Masa birahi bulan Juli-September dan kelahiran pada bulan Mei-Juni dengan jumlah anak yang dilahirkan bisanya satu ekor, sedangkan beranak antara anak pertama dan anak kedua berjarak satu tahun empat bulan, keadaan ini tidak berbeda dengan yang dilaporkan Hoogerwerf ( 1970).

\section{Habitat dan Tumbuhan Pakan}

Habitat rusa di P. Peucang dari dua tipe komunitas (hutan mangrove dan dataran rendah) berupa padang rumput, hutan mangrove, hutan pantai, dan hutan dataran rendah (10-30 $\mathrm{m} \mathrm{dpl})$.

Jumlah jenis dan jumlah pohon yang terdapat pada tiap jalur rintisan serta jumlah jenis dan pohon yang disukai rusa dapat dilihat pada Tabel 3 .

Tabel (Table) 3. Jumlah jenis dan pohon yang disukai rusa pada tiap jalur (Number of species and trees preference of deer on each treatment)

\begin{tabular}{|c|l|c|c|c|c|}
\hline No. & $\begin{array}{c}\text { Jalur Rintis } \\
\text { (Line Transect) }\end{array}$ & $\begin{array}{c}\text { Jumlah Jenis } \\
\text { Dominan } \\
\text { (Number of } \\
\text { Dominant } \\
\text { Species) }\end{array}$ & $\begin{array}{c}\text { Jenis Disukai } \\
\text { (Species } \\
\text { Preferenced) }\end{array}$ & $\begin{array}{c}\text { Jumlah Pohon } \\
\text { Dominan } \\
\text { (Number of } \\
\text { Dominant trees) }\end{array}$ & $\begin{array}{c}\text { Jumlah } \\
\text { Pohon yang } \\
\text { Disukai } \\
\text { (Trees } \\
\text { Preferenced) }\end{array}$ \\
\hline 1. & Pantai Barat & 31 & $18(58,0 \%)$ & 45 & $25(55,5 \%)$ \\
\hline 2. & Jalan Patroli & 15 & $11(73,3 \%)$ & 31 & $22(70,9 \%)$ \\
\hline 3. & Bukit & 20 & $14(70,0 \%)$ & 28 & $24(63,0 \%)$ \\
\hline 4. & Pantai Timur & 16 & $10,(62,0 \%)$ & 30 & $21(70,0 \%)$ \\
\hline
\end{tabular}

Tabel 3 menunjukkan jenis pohon yang disukai rusa berkisar antara 58-73,3 $\%$ atau rata-rata $65,8 \%$ dari seluruh jenis yang ada. Sedangkan jumlah pohon yang disukai rusa berkisar antara 55,5-70,9\% atau rata-rata $64,8 \%$, dari semua pohon yang terdapat pada ke empat jalur rintis tersebut. Hal ini memberikan kesan yang menggembirakan jika ditinjau dari segi cadangan pakan rusa untuk jangka panjang, karena pohon-pohon itulah yang dapat diharapkan menambah jumlah anakan dan belta sebagai sumber pakan rusa pada masa yang akan datang. Sebagai gambaran keadaan jenis tumbuhan di habitat rusa dalam 15 petak coba dan sepanjang transek garis seperti tertera pada Lampiran 1. 


\section{Kebutuhan Hijauan Pakan/Ekor/ Hari}

Berdasarkan hasil pengamatan terhadap 5 ekor rusa betina dewasa dengan 5 kali ulangan dengan sistem kandang, maka besarnya kebutuhan hijauan pakan rata-rata per ekor per hari adalah $5,7 \mathrm{~kg}$ hijauan segar/ ekor/hari atau $0,5 \mathrm{~kg}$ berat kering. Jika dibandingkan dengan kebutuhan hijauan segar sebagai pakan rusa per ekor per hari di Taman Buru P. Moyo (4,42 kg hijauan segar/ekor/hari atau $0,97 \mathrm{~kg}$ hijauan kering), maka kebutuhan hijauan segar/ekor/hari di P. Peucang lebih tinggi $1,28 \mathrm{~kg}$.

Namun kebutuhan nyata dikaji berdasarkan kebutuhan hijauan kering, dengan demikian kebutuhan hijauan pakan per ekor per hari menjadi sebaliknya yaitu kebutuhan hijauan pakan rusa P. Moyo lebih tinggi jika dibandingkan dengan rusa $P$. Peucang. Penyebabnya adalah antara lain adanya variasi umur dalam kelas umur dewasa dan sex ratio yang berbeda yaitu sampel di P. Peucang 5 ekor betina dewasa, sedangkan di P. Moyo 5 ekor betina dewasa 3 betina remaja.

\section{Daya Dukung Habitat Rusa}

Daya dukung habitat rusa di Pulau Peucang, baru dikemukakan pada musim hujan, yaitu bulan November-Februari yang berpengaruh terhadap produksi hijauan pakan rusa, baik berupa rumput maupun daun-daunan dari terna/semai/belta.

Produksi kering pakan berupa daundaunan dan rumput-rumputan, yaitu 6331,81 $\mathrm{kg}$ per hektar, terdiri dari $137,21 \mathrm{~kg}$ per hektar daun-daunan dan $6194,60 \mathrm{~kg}$ per hektar rumput. Jadi produk kering hijauan daun-daunan yang tersedia bagi rusa adalah $137,21 \times 0,45$ (P.U) x $439 \mathrm{~kg}=27.105,30$ $\mathrm{kg}$, dan produk kering rumput-rumputan yang tersedia adalah $6194,6 \mathrm{~kg} / \mathrm{ha} \times 0,7$ (P.U) $\times 0,75 \mathrm{ha}=3252,20 \mathrm{~kg}$. Jadi daya dukung habitat rusa berupa rumputrumputan dihitung berdasarkan pada kemampuan produksi rumput-rumputan dan kebutuhan pakan rusa dibagi kebutuhan berat kering pakan rusa per ekor per musim $(180 \times 0,5)=36,13$ ekor. Sedangkan daya dukung habitat rusa berupa hijauan daundaunan adalah $27.105,30$ dibagi $(180 \times 0,5)$
$=301,17$ ekor.

Daya dukung habitat rusa $P$. Peucang pada musim hujan adalah $36,13+301,17$ ekor $=337,30$ ekor. Jadi pada musim hujan yaitu antara 271-30m dua kali pengamatan kondisi di bara 271-308 ekor, masih dalam Namun, peman daya dukung maksimum. populasi rusa rumput terus dan manemen habitat padang populasi rusa ditingkatkan. Manajemen penangkapan dilakukan dengan cara dewasa yang tidaktif terhadap rusa $\mathrm{KU}$

B. Biawak

1. Populasi, Kelas Umur dan Nisbah
Kelamin Menurut hasil

lokasi pengamat pengamatan pada 12 Peucang sekitar 55 bahwa biawak di P. dewasa 46 ekor (betior, terdiri dari KU 10 ekor), KU remaja 36 ekor dan jantan dan jantan 2 ekor) 7 ekor (betina 5 ekor (betina), secara rin) dan KU anak 2 ekor dapat dilihat pada Tabel 4 . 


\section{Kebutuhan Hijauan Pakan/Ekor/ Hari}

Berdasarkan hasil pengamatan terhadap 5 ekor rusa betina dewasa dengan 5 kali ulangan dengan sistem kandang, maka besarnya kebutuhan hijauan pakan rata-rata per ekor per hari adalah $5,7 \mathrm{~kg}$ hijauan segar/ ekor/hari atau $0,5 \mathrm{~kg}$ berat kering. Jika dibandingkan dengan kebutuhan hijauan segar sebagai pakan rusa per ekor per hari di Taman Buru P. Moyo (4,42 kg hijauan segar/ekor/hari atau $0,97 \mathrm{~kg}$ hijauan kering), maka kebutuhan hijauan segar/ekor/hari di P. Peucang lebih tinggi $1,28 \mathrm{~kg}$.

Namun kebutuhan nyata dikaji berdasarkan kebutuhan hijauan kering, dengan demikian kebutuhan hijauan pakan per ekor per hari menjadi sebaliknya yaitu kebutuhan hijauan pakan rusa P. Moyo lebih tinggi jika dibandingkan dengan rusa $P$. Peucang. Penyebabnya adalah antara lain adanya variasi umur dalam kelas umur dewasa dan sex ratio yang berbeda yaitu sampel di P. Peucang 5 ekor betina dewasa, sedangkan di P. Moyo 5 ekor betina dewasa 3 betina remaja.

\section{Daya Dukung Habitat Rusa}

Daya dukung habitat rusa di Pulau Peucang, baru dikemukakan pada musim hujan, yaitu bulan November-Februari yang berpengaruh terhadap produksi hijauan pakan rusa, baik berupa rumput maupun daun-daunan dari terna/semai/belta.

Produksi kering pakan berupa daundaunan dan rumput-rumputan, yaitu 6331,81 $\mathrm{kg}$ per hektar, terdiri dari $137,21 \mathrm{~kg}$ per hektar daun-daunan dan $6194,60 \mathrm{~kg}$ per hektar rumput. Jadi produk kering hijauan daun-daunan yang tersedia bagi rusa adalah $137,21 \times 0,45$ (P.U) x $439 \mathrm{~kg}=27.105,30$ $\mathrm{kg}$, dan produk kering rumput-rumputan yang tersedia adalah $6194,6 \mathrm{~kg} / \mathrm{ha} \times 0,7$ (P.U) $\times 0,75 \mathrm{ha}=3252,20 \mathrm{~kg}$. Jadi daya dukung habitat rusa berupa rumputrumputan dihitung berdasarkan pada kemampuan produksi rumput-rumputan dan kebutuhan pakan rusa dibagi kebutuhan berat kering pakan rusa per ekor per musim $(180 \times 0,5)=36,13$ ekor. Sedangkan daya dukung habitat rusa berupa hijauan daundaunan adalah $27.105,30$ dibagi $(180 \times 0,5)$
$=301,17$ ekor.

Daya dukung habitat rusa $P$. Peucang pada musim hujan adalah $36,13+301,17$ ekor $=337,30$ ekor. Jadi pada musim hujan yaitu antara 271-30m dua kali pengamatan kondisi di bara 271-308 ekor, masih dalam Namun, peman daya dukung maksimum. populasi rusa rumput terus dan manemen habitat padang populasi rusa ditingkatkan. Manajemen penangkapan dilakukan dengan cara dewasa yang tidaktif terhadap rusa $\mathrm{KU}$

B. Biawak

1. Populasi, Kelas Umur dan Nisbah
Kelamin Menurut hasil

lokasi pengamat pengamatan pada 12 Peucang sekitar 55 bahwa biawak di P. dewasa 46 ekor (betior, terdiri dari KU 10 ekor), KU remaja 36 ekor dan jantan dan jantan 2 ekor) 7 ekor (betina 5 ekor (betina), secara rin) dan KU anak 2 ekor dapat dilihat pada Tabel 4 . 
Tabel (Table) 4. Populasi biawak (V. salvatori) di Pulau Peucang T.N. Ujung Kulon Provinsi Banten, tahun 2001(Monitor lizard population in Peucang Island, Ujung Kulon National Park, Banten Province, 2001)

\begin{tabular}{|c|c|c|c|c|c|c|c|c|c|}
\hline \multirow{3}{*}{ No. } & \multirow{3}{*}{$\begin{array}{c}\text { Lokasi } \\
\text { Location }\end{array}$} & \multicolumn{6}{|c|}{ Kelas Umur (Age Class/Year) } & \multirow{2}{*}{\multicolumn{2}{|c|}{$\begin{array}{l}\text { Jumlah } \\
\text { (Total) }\end{array}$}} \\
\hline & & \multicolumn{2}{|c|}{$\begin{array}{l}\text { Dewasa } \\
(\text { Adult })\end{array}$} & \multicolumn{2}{|c|}{$\begin{array}{c}\text { Remaja } \\
\text { (Adolescent) }\end{array}$} & \multicolumn{2}{|c|}{$\begin{array}{c}\text { Anak } \\
\text { (Juvenile) }\end{array}$} & & \\
\hline & & + & 8 & 9 & 8 & $\frac{10}{9}$ & $\frac{1}{6}$ & q & 8 \\
\hline 1. & Pasangrahan & 4 & 1 & 1 & - & - & - & 5 & 1 \\
\hline 2. & Jl. Ke Kr. Copong & 3 & 1 & - & - & - & - & 3 & 1 \\
\hline 3. & Lg. Beton & 6 & 2 & 2 & 1 & - & - & 8 & 3 \\
\hline 4. & Cihandarusa & 3 & - & - & 1 & 2 & - & 5 & 1 \\
\hline 5. & Belakang Diesel & 5 & 1 & - & - & - & - & 5 & 1 \\
\hline 6. & Kr. Copong & 2 & - & - & - & - & - & 2 & - \\
\hline 7. & G. Peucang Barat & & - & - & - & - & - & 1 & - \\
\hline 8. & Ciapus & 3 & 1 & - & - & - & - & 3 & 1 \\
\hline 9. & Lg. Kobak & 4 & 2 & - & - & & - & 4 & 2 \\
\hline 10. & Lg. Sumino & 2 & 1 & 1 & - & - & - & 3 & 1 \\
\hline 11. & GB Peucang Timur & 1 & - & 1 & - & - & - & 2 & - \\
\hline 12. & Ranca Waru & 2 & 1 & - & - & - & - & 2 & 1 \\
\hline & Jumlah (Total) & 36 & 10 & 5 & 2 & 2 & - & 43 & 12 \\
\hline
\end{tabular}

Pada Tabel 4 tersebut, terlihat populasi biawak pada $\mathrm{KU}$ anak/bayi sangat sedikit, sedangkan pada KU dewasa nisbah kelamin jantan-betina adalah hampir $1: 4$, dan ini memungkinkan untuk terbentuknya struktur umur yang berbentuk piramid, artinya populasi biawak $\mathrm{KU}$ anak, lebih besar dari populasi biawak KU remaja dan seterusnya. Namun, ada perilaku yang memungkinkan populasi remaja dan atau anak menurun. Perilaku umum biawak ini hampir mirip komodo yaitu bersifat kanibal, kemungkinan anak yang baru lahir/menetas dari telur dimakan. Hal ini disebabkan anak biawak tersebut yang secara naluriah begitu lahir lari mencari perlindungan di lubang-lubang pohon atau tempat lain yang berlubang, di sini anak biawak tersebut menetap sampai dia dapat bertahan hidup dengan lingkungan terutama dari predator. Pada masa di dalam lubang, makanannya serangga.

Kaitannya dengan ketersediaan habitat bagi anak biawak terutama pohon-pohon tempat berlindung/berlubang di P. Peucang selama pengamatan dapat dikatakan cukup, tapi ketersediaan habitat biawak remaja dan dewasa berupa rawa/air tergenang sebagai habitat pakan hanya ada satu tempat. Hal ini dimungkinkan ketersediaan pakan biawak lainnya berupa ikan dan atau bangkai hanya yang ada di pantai. Jika peluang ini kecil maka kemungkinan dugaan populasi $\mathrm{KU}$ anak rendah, disebabkan kanibalisme induk biawak. Sebaliknya jika peluang ketersediaan pakan tinggi, sedangkan keadaan populasi $\mathrm{KU}$ anak biawak rendah saat pengamatan, kemungkinan anak-anak biawak banyak berlindung di lubang-lubang pohon atau tempat berlindung lainnya, sehingga tidak tersensus pada waktu pengamatan. Oleh karena itu perlu adanya pemantauan terhadap ketersediaan habitat dan pemanfaatannya oleh biawak KU anak.

\section{Daya Dukung Habitat Biawak}

Jenis pakan biawak di alam pada umumnya terdiri dari ikan, serangga, telur penyu, tukik (anak penyu), telur burung, dan bangkai hewan. Ketersediaan jenis pakan biawak di P. Peucang hampir semua tersedia, kecuali telur penyu atau tukik yang tidak ada, karena tidak adanya pantai berpasir sebagai habitat bertelur penyu. 
Daya dukung habitat dengan pendekatan jumlah ketersediaan pakan dan kebutuhan pakan per ekor per hari tidak dilakukan, karena dukungan fasilitas dan sarana penelitian tidak tersedia. Selanjutnya daya dukung habitat biawak pendekatannya melalui kerapatan individu per hektar.

Luas P. Peucang adalah 450 ha terdiri dari kawasan bervegetasi hutan/pohon sekitar 439 ha dan sisanya berupa bangunan untuk administrasi pengelolaan dan padang rumput. Kawasan hutan 439 ha sebagai habitat biawak, berarti kerapatan populasi adalah 55 ekor per 439 ha atau 0,13 ekor per ha. Menurut pengamatan di lapangan keadaan biawak tampaknya hidup sehat, dan kuat serta gerakannya lincah ketika bahaya mengancamnya. Menurut Wiersum (1973), populasi pada batas daya dukung demikian ada pada tingkat kerapatan populasi optimum.

\section{KESIMPULAN DAN SARAN}

\section{A. Kesimpulan}

1. Rusa

a. Populasi rusa di P. Peucang menurun dari 300 ekor (tahun 2000) menjadi 271 ekor (tahun 2001). Fluktuasi ini disebabkan dua faktor yaitu : pertama emigrasi karena selama pengamatan dijumpai beberapa kelompok rusa dewasa menyeberang ke pantai Ujung Kulon daratan P. Jawa, dan kedua faktor kematian karena usia yang terlalu tua dari kelompok rusa dewasa, dan penyakit dari kelompok kelas umur bayi/anak

b. Populasi rusa 271 ekor terdiri dari kelas umur dewasa 131 ekor (betina 104 ekor dan jantan 27 ekor), kelas umur remaja 63 ekor (betina 46 ekor dan jantan 17 ekor) dan kelas umur anak/bayi 77 ekor (betina 56 ekor dan jantan 21 ekor).

c. Habitat rusa di P. Peucang dari dua tipe komunitas (mangrove dan hutan pantai, dan dataran rendah) berupa padang rumput, hutan mangrove, hutan pantai, dan hutan dataran rendah $(10-30 \mathrm{~m} \mathrm{dpl})$. d. Jumlah jenis tumbuhan bukan pohon dan yang disukai sebagai pakan rusa yaitu berkisar antara 58,0 - 73,3\% atau ratarata $65,8 \%$ dari seluruh jenis yang ada. Sedangkan jumlah pohon yang disukai rusa berkisar antara 55,5 - 70,9\%, atau rata-rata $64,8 \%$ dari semua jenis pohon yang terdapat dalam jalur coba.

e. Besarnya kebutuhan hijauan pakan ratarata per ekor per hari adalah $5,7 \mathrm{~kg}$ hijauan segar/ekor/hari atau $0,5 \mathrm{~kg}$ berat

f. Daya dukung habitat rusa P. Peucang pada musim hujan 337 ekor, dan pada musim ini populasi rusa dalam dua kali pengamatan yaitu antara $271-308$ ekor, masih dalam kondisi di bawah daya dukung maksimum.

\section{Biawak}

a. Populasi biawak di P. Peucang sekitar 55 ekor terdiri dari KU dewasa 46 ekor (betina 36 ekor dan jantan 10 ekor), KU remaja 7 ekor (betina 5 ekor dan jantan 2 ekor) dan KU anak 2 ekor (betina).

b. Jenis pakan biawak di P. Peucang terdiri dari ikan, serangga, telur burung, dan c. Daya dukung biawak setara dengan
kerapatan populasi optimung ekor per ha.

\section{B. Saran}

1. Manajemen habitat padang rumput perlu ditingkatkan, demikian pula majemen bawah daya dukehingga tetap ada di

2. Perlu adanyakung habitatnya. pakan dan pemantauan ketersediaan biawak KU anak/bayi.

\section{DAFTAR PUSTAKA}

Hoogerwerf, A. 1970 . Ujung Kulon. The
land of the last Javan Rhinoceros. E. J.
Brill Leiden, 512 p. 
Lavieren, Van. L.P. 1983. Wildlife Management in the Tropics. A guidebook for Warden Part 2. School of Environmental Conservation Management, Ciawi Bogor, p.58-78.

McIlroy, R.J. 1964. An Introduction to Tropical Grassland Husbandry. Oxford Univ. Press. diterjamahkan oleh Soesetyo, S. et al 1977. Pradnya Paramita, Jakarta. 168 pp.

Mukhtar, A. S. 1996. Studi Dinamika Populasi Rusa (Cervus timorensis Blainville) dalam Menunjang Taman Buru Pulau Moyo Provinsi Nusa Tenggara Barat. Disertasi Program Pasca Sarjana IPB. 229 p.
Mukhtar, A. S. 2000. Penentuan Jatah Tangkap Rusa dan Biawak dalam Rangka Pengendalian Populasi di TN Ujung Kulon. Laporan Tahunan 2000. Proyek Penelitian dan Pengembangan Hutan Tanaman, Puslitbang Hutan dan Konservasi Alam Bogor.

Soesetyo. 1975. Pemikiran Dasar Fisiologi Teknis Untuk Perkiraan Kemampuan Penyediaan Hijauan. Departemen Ilmu Makanan Ternak. IPB, Bogor.

Wiersum, K.F. 1973. Wildlife Utilization and Management in Tropical Region. Agric. Univ Wageningen. Netherland, p. 33-40. 
Lampiran (Appendix) 1. Daftar jenis tumbuhan dan hijauan pakan rusa di Pulau Peucang, T.N. Ujung Kulon (List of plant species and feeds of deers in Peucang Island, Ujung Kulon National Park)

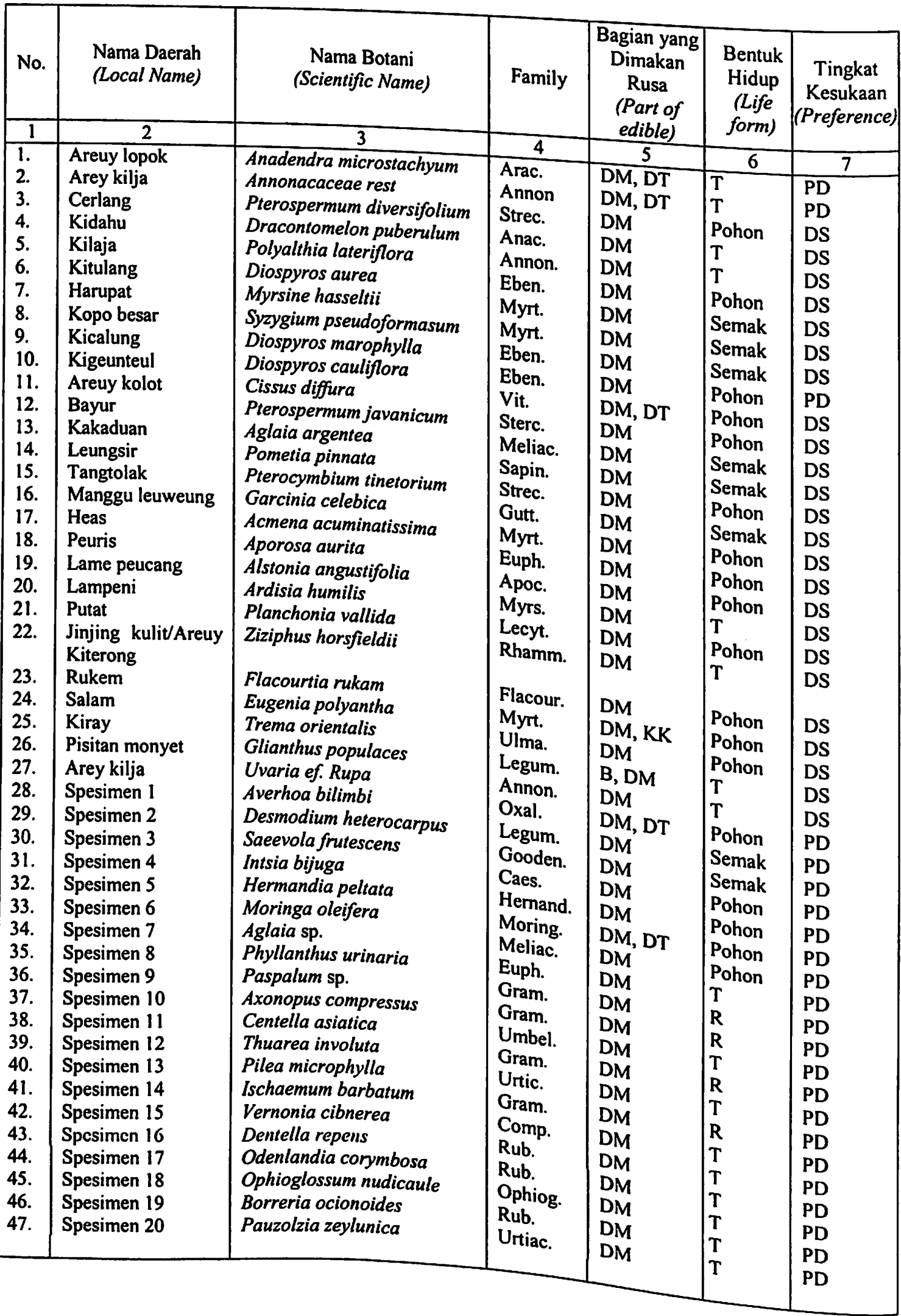


Lanjutan (Continued)

\begin{tabular}{|c|c|c|c|c|c|c|}
\hline 1 & 2 & 3 & 4 & 5 & 6 & 7 \\
\hline 48. & Spesimen 21 & Cyperus sp. & Cyper. & $\overline{D M}$ & $\mathrm{R}$. & PD \\
\hline 49. & Spesimen 22 & Portulaca oleraceae & Port. & $\mathrm{DM}$ & $\mathrm{T}$ & PD \\
\hline 50. & Spesimen 23 & Euphorbia hirta & Euph. & $\mathrm{DM}$ & $T$ & PD \\
\hline 51. & Spesimen 24 & Digitaria sp. & Gram. & DM & $\mathbf{R}$ & PD \\
\hline 52. & Spesimen 25 & Desmodium trifolium & Legum & DM & $\mathrm{T}$ & PD \\
\hline 53. & Spesimen 26 & Fimbristylus cymosa & Cyper. & DM & R. & PD \\
\hline 54. & Spesimen 27 & Lumnitzera racemosa & Comb. & $\mathrm{DM}$ & Rumput & PD \\
\hline 55. & Spesimen 28 & Hibiscus tiliaceus & Kalva. & DM, DT & Pohon & PD \\
\hline 56 & Spesimen 29 & Spondias pinnata & Anac. & DM, B & Pohon & DS \\
\hline 57. & Spesimen 30 & Bischoffia javanica & Euph. & DM, DT & Pohon & DS \\
\hline 58. & Spesimen 31 & Garsinia dulcis & Gutt. & $\mathrm{DM}$ & Pohon & DS \\
\hline 59. & Spesimen 32 & Baringtonia asiatica & Lecy. & $\mathrm{DM}$ & Pohon & DS \\
\hline 60 & Spesimen 33 & Malotus mortizianus & Euph. & DM, DT & Pohon & DS \\
\hline 61. & Spesimen 34 & Ceiba petandra & Bomb. & DM, DT,B & Pohon & DS \\
\hline 62. & Spesimen 35 & Kleinhovia hospita & Ster. & UDM,TDM & Pohon & DS \\
\hline 63. & Spesimen 36 & Sophora tomentosa & Legum. & $\mathrm{DM}$ & Semak & DS \\
\hline 64. & Spesimen 37 & Polyalthia lateriflora & Anon. & DM & Pohon & DS \\
\hline 65. & Spesimen 38 & Pisonia umbellifera & Nyeta. & $\mathrm{DM}, \mathrm{KKP}$ & Pohon & DS \\
\hline 66. & Spesimen 39 & Pentace polyantha & Tilia. & DM,DT & Pohon & DS \\
\hline 67. & Spesimen 40 & Terminalia catappa & Comb. & DM & Pohon & DS \\
\hline 68. & Spesimen 41 & Tylophora sp. & Axilia. & DM & Liana & DS \\
\hline 69. & Spesimen 42 & Aphanamixis sp. & Melia. & BUDM & Pohon & DS \\
\hline 70. & Spesimen 43 & Ficus sp. & Morac. & DM & Pohon & DS \\
\hline 71. & Spesimen 44 & Gnetum sp. & Gneta. & DM & Pohon & DS \\
\hline 72. & Spesimen 45 & Drynaria quereifolia & Poly. & BUDM & Epifit & DS \\
\hline 73. & Spesimen 46 & Salacia korthalsiana & Hippo. & DM & Pohon & DS \\
\hline 74. & Spesimen 47 & Ardisia humilis & Myrs. & DM & Pohon & DS \\
\hline 75. & Spesimen 48 & Cryptocarya montok & Laur. & DM & Pohon & DS \\
\hline 76. & Spesimen 49 & Macaranga sp. & Euph. & DM, DJ & Pohon & DS \\
\hline 77. & Spesimen 50 & Allophyllus cobbe & Sapin. & DM & Semak & $\mathrm{KD}$ \\
\hline 78. & Spesimen 51 & Aglaia argentea & Meliac. & DM & Pohon & KD \\
\hline 79. & Spesimen 52 & Schefflera alliptica & Aralia. & PCD & Pohon & KD \\
\hline 80. & Spesimen 53 & Vicus veriegata & Morac. & BT & Pohon & $\mathrm{KD}$ \\
\hline 81. & Spesimen 54 & Canophyllum falcatum & Sapin. & DM & Pohon & KD \\
\hline 82. & Spesimen 55 & Eugenia sp. & Myrt. & BT & Pohon & KD \\
\hline 83. & Spesimen 56 & Xerospermum sp. & Sapin. & DM & Pohon & $\mathrm{KD}$ \\
\hline 84. & Spesimen 57 & Eugenia subglauca & Myrt. & DM & Pohon & KD \\
\hline 85. & Spesimen 58 & Sterculia coccinea & Ster. & BT,BM & Pohon & KD \\
\hline 86. & Spesimen 59 & Pandanus sp. & Pandan. & PCD & Herba & $\mathrm{KD}$ \\
\hline 87. & Spesimen 60 & Garcinia celebica & Gutt. & DM & Pohon & KD \\
\hline 88. & Spesimen 61 & Pterospermum javanicum & Ster. & PCD & Pohon & KD \\
\hline 89. & Spesimen 62 & Pandanus tectorius & Pandan. & PCD & Pohon & $\mathrm{KD}$ \\
\hline 90. & Spesimen 63 & Cinnamomum iners & Laur. & $\mathrm{DM}$ & Pohon & KD \\
\hline 91. & Spesimen 64 & Mangifera sp. & Anac. & BT, DT & BM,BT & $\mathrm{KD}$ \\
\hline
\end{tabular}

Keterangan (Remarks): DM=Daun Muda (young leaf), DT=Daun Tua (old leaf), $\mathrm{PCD}=\mathrm{Pucuk}$ Daun (bud), B=Buah (fruit), BM=Buah Muda (unripe fruit), BT=Buah Tua (ripe fruit), DMBU=Daun Muda Bagian Ujung (tip of young leaf), $\mathrm{KK}=\mathrm{Kulit}$ Kayu (tree bark), DJ=Daun Jatuh (fallen leaf), $\mathrm{T}=$ Terna, $\mathrm{R}=\mathrm{Rumput}$ (grass), $\mathrm{PD}=$ Paling Disukai (most preferred), DS = Disukai Sedang (medium preferred), dan $\mathrm{KD}=$ Kurang Disukai (less preferred). 